\title{
International Literacy Research Projects at Kecskemét College Teacher Training Faculty, Hungary
}

\author{
Ildikó Szabó \\ Kecskeméti Főiskola Tanítóképző Főiskolai Kar/Modern Nyelvek Intézete, Kecskemét, Hungary \\ *Corresponding Author:balazsne.ildiko@tfk.kefo.hu
}

Copyright (C) 2014 Horizon Research Publishing All rights reserved.

\begin{abstract}
Reading and understanding texts of all kinds form a basic competence for participating in social and cultural life and for being successful on a job. Although most European adolescents have adequate reading competences at their disposal by the end of school, about a quarter of them cannot meet the minimal standards. The urgency of this societal problem has induced the European Commission to invite tenders to find reasons for this phenomenon and give ideas how to handle and solve the problem. Kecskemét College Teacher Training Faculty entered the first international project in the field in 2006 (ADORE) looking for good school practices all over Europe. It was followed by designing and implementing an in-service teacher training course (BaCuLit), of which follow-up is an international association to promote this knowledge among $\mathrm{PhD}$-students (ISIT). At the moment we are in the process of writing a proposal of European Literacy Network (EuLit).
\end{abstract}

Keywords Struggling Readers, Content Area Literacy, In-Service Teacher Training, Research Network

\section{Introduction}

Kecskemét College Teacher Training Faculty entered international research on literacy in 2006 by being a member of ADORE Project. Since then on a research team has been investigating the elements of good literacy practices, making them available for in-service teachers through training courses, building up an international network of researchers in the field and disseminating the results.

\section{Materials and Methods}

\subsection{The ADORE Project}

The ADORE-Project has investigated into the reading instruction for adolescent struggling readers in 11 European countries and searched for examples of "good practice" in the enhancement of these students. The participants of this project were reading experts from universities and teacher-training-institutions from the following countries: Austria, Belgium, Estonia, Finland, Germany, Hungary, Italy, Norway, Poland, Romania and Switzerland.

The ADORE-Project was explicitly interested in the input; we have asked: Which are the components of "good practice" in order to support adolescent low achievers in reading? The project focused especially on the instructional practice in public secondary schools (including vocational schools). So, it does not claim to encompass all forms of reading enhancement. ASR belong to an age group from 12 to 18 years. ASR are already readers, they are not illiterate. Nonetheless, they did not develop the reading skills which enable them to react adequately on demands of their rapidly changing professional and private lives. Most of them did not develop a stable self-concept of being a reader. Their reading is hindered by obstacles they can not yet overcome by themselves. These obstacles are mainly in the areas of decoding, reading fluency, reading comprehension, meta-cognitve skills, use of reading strategies, and reading motivation. To overcome these obstacles, they need the help of competent others, especially the help of professional teachers.

The probability of a child developing into a "struggling reader" varies in the different European countries. According to PISA 2006, only $4.8 \%$ of Finnish 15 -year-olds, but $53.5 \%$ of Romanian youth were low performers in reading. How much a child struggles with reading, how long and with what consequences, depends largely on their country of origin and its educational system. The European countries, which we have compared in the ADORE-Project, vary in their socio-economic pre-conditions; for this reason a fair comparison between them can hardly be drawn. The countries we examined provide different legal and financial resources for dealing with struggling readers. They are characterized by different educational systems, different curricula and different educational cultures.

Most of the educational systems we examined have not, up till now, faced the challenge $f$ guaranteeing a high-quality standard of reading literacy. There is a deplorable discrepancy $n$ this area between the urgency of 
the problem and the absence of concepts. While this general description also applies to many wealthy Western European countries (like for instance he Federal Republic of Germany), the problem is even more pronounced in many Eastern European countries because of their weaker economies on the one hand, and because of their particularly traditional educational policies and educational cultures, on the other hand. Especially, elective educational systems with a very strict set of subjects and very prescriptive curricula make hardly any attempts to meet these new challenges adequately.

Many Anglo-American and Nordic countries have been conscious of the problem of reading literacy for two or three decades now, which is reflected in the level of international reading research. In contrast, most of the other European countries have only developed this consciousness as a result of the PISA-Surveys; in some countries it still does not even exist.

As a consequence, many European countries hardly have any concepts for the systematic enhancement of reading literacy beyond early and middle childhood. Furthermore, many parts of Europe still lack professional organizations as well as informal networks, national and international publication organs, or internet-platforms - in short: A developed communication structure for professionals (researchers and practitioners). Accordingly, public and political attention has hardly turned to this problem.

In most European countries, literacy studies neither have a place in the organization of universities nor in teacher training beyond elementary reading instruction in the first classes of primary school. The concept of reading as an enormously complex and, to a large extent, subject-specific task, that has to be fostered systematically on all class-levels and in all content areas, is foreign to most European school systems: Learning to read and write is seen as a task of mother-tongue instruction in the first two or three school years; afterwards, these skills are taken for granted and from then on mother-tongue as well as content area instruction concentrates on conveying specialized subject-knowledge. To international reading research, on the contrary, it is evident that reading and writing skills must be developed continuously and subject-specifically in all content areas. As little as these findings have informed the teacher training at universities, so little have they been the starting point for installing a systematic and continuous reading curriculum for schools which would model the necessary progress of academic literacy across all subject areas and class-levels. One of the reasons for this could be found in the existence of separate elementary and secondary schools (or even of three different school levels: elementary, middle and upper level) which result in different curricula and accordingly, prevent the modelling of competences in national curricula.

A further serious deficit can be found in the diagnosis of reading competences: In many European countries, there are hardly any tests or other reliable assessment procedures, so that the teachers are left alone with the task of identifying poor readers. Several studies have indicated that the diagnostic competences of many teachers are not sufficiently developed and that they do not recognize "problem cases". This is primarily a challenge for politics, research and teacher training. In many of the countries we have examined, there is no systematic reading research, which would have the task of discussing and installing curricula and educational standards, of developing diagnostic instruments and procedures for assessment and evaluation, as well as working on further teacher qualification.

As a consequence of these deficits, we can underline: In most European countries, there is no systematic continuing reading training in the context of content area instruction, beyond the first two class-levels. Therefore, adolescents struggling with reading do not find any support; their subject-specific learning potentials and interests cannot unfold because of comprehension problems. Consequently, their performance is poor. With these deficits, they are cut off from higher educational qualifications and correspondingly from the better jobs. Society leaves a lot of educational potential unused

This focal point is based on the idea that the deficits of ASR require well-directed, long term measures of the institution school and cannot be eliminated by short-term reading campaigns. The most important results could be summarized in 13 Key Elements of good practice and one "superior goal" that were published and thouroughly introduced in ADORE book published in 2010.

\subsection{The BaCuLit Project}

The follow-up of ADORE Project was BaCuLit. This Comenius project is based on the results of the international ADORE-study: "Teaching Adolescent Struggling Readers A Comparative Study of Good Practices in European Countries", funded by the European Socrates Program from 2006 to 2009 (Summary of the project's results can be downloaded from: www.adore-project.eu). The $\mathrm{BaCuLit}-$ project intends to develop, test and implement a Basic Curriculum for Teachers' In-service Training in Content Area Literacy in Secondary Schools [BaCuLit]. For this purpose, 10 partners from universities and in-service teacher training institutions from 7 European countries cooperate in this project; they are supported and consulted by two American experts (duration of the project: 01/2011 12/2012) including a module developed by the Hungarian partner.

The project was located within the horizon of "learning skills" but focuses on "reading skills": It intends to extend secondary school teachers' expertise to improve their students' fluency, reading habits and comprehension strategies for diverse texts in all school subjects and to help them building a stable self-concept as readers and learners. Most urgent in this respect is to foster the so called "content area reading literacy" or "reading across the curriculum". The term "content area literacy" refers to teachers' 
competence to deal with reading/writing/learning instruction not only on the elementary level in the language arts classes, but in all subjects and all school levels. The project uses a "multiplier- and coaching-approach" which means that first, teacher trainers are educated and then will be supported in educating a first teacher cohort and in sustaining those teachers' change of classroom practice.

The basic curriculum defines the minimal knowledge every secondary content area teacher in the EU should have about teaching reading skills in all school subjects. It will provide 6 modules of 6 hours professional development course units each, including teaching material, collaborative tasks for improving one's own classroom practice and online support. Although the basic curriculum was only implemented in 6 European countries, it defines the first overall European minimal standard for in-service teacher training in content area literacy. After being tested, the concept of the basic curriculum will therefore be downloadable on the project's website in English and the partners' languages.

BaCuLit defines the first overall European minimal standard as well as research-based principles for in-service teacher training in content area literacy. The BaCuLit Project offers a course containing six modules which include a complete teaching material set of PPTs, worksheets, a Teachers' Workbook and a Trainer's Handbook with work plans for every course unit and theoretical background information. These Modules contain 'essential' and 'optional' content and can be taught flexibly, according to national conditions and the needs of diverse schools, teaching staff or single teachers.

The $\mathrm{BaCuLit}$ project addresses all decision makers in educational policy and in schools who are responsible for the training of secondary school teachers. However, the main target groups are the content area teachers participating in the $\mathrm{BaCuLit}$ course in order to improve their own instruction or to become future $\mathrm{BaCuLit}$ trainers. Finally, the students will benefit from the increased expertise of their teachers due to the teachers knowing how to support their students by providing guided text comprehension. Furthermore, the project offers teacher training institutions and decision makers from educational policies an evaluated core curriculum for the education and training of teachers which allows to reduce the striking deficits of adolescents in reading literacy.

In the last project phase of the BaCuLit project, 12 partners from 7 countries founded a registered non-profit BaCuLit-Association (www.baculit.eu) as a platform for the cooperation of scientists, teacher educators and stakeholders aiming at implementing the $\mathrm{BaCuLit}$ results into teacher training, especially into teachers' Professional Development. On the 3rd BaCuLit Workshop in Cologne (in august 2012) the coordinating team together with the head of the Office of Entrepreneurship at the University of Cologne (Mr. Ziegler) had developed a proposal that suggested the establishment of an international BaCuLit-Association. Main goal of establishing an association is to create a legal entity that will take over the ownership of the "intellectual property" worked out by the project; this includes the trademark "BaCuLit" and the copyright of all materials. The purpose of the BaCuLit Association is to preserve $\mathrm{BaCuLit}$ as high quality label for teacher training; it might be implemented in different ways in different countries (e.g. in in-service teacher training or in pre-service training) but should define common quality standards which have to be proved in order to get certified as a BaCuLit teacher or BaCuLit trainer.

\subsection{The ISIT Project}

As a result of these mainstreaming reports the project coordinator (Prof. Garbe / Martin Gross) submitted a proposal in Comenius "Accompanying Measures" in January 2013: "ISIT - Implementation Strategies for Innovations in Teachers' Professional Development". The core partners in this project proposal are 3 out of $7 \mathrm{BaCuLit}$ countries - Germany, Romania, and Hungary - as their mainstreaming concepts showed the most promising opportunities to implement the BaCuLit curriculum within a narrow time-frame. Besides this, the 3 countries represent different approaches to CPD (= Continuous Professional Development) and diverse structures (central, federal, regional), so that a comparative analysis will deliver rich insights. The specific goal of ISIT will be to establish CAL (= content area literacy) in secondary school teachers' professional development. In Germany, Hungary and Romania a total of 30 trainers from different teacher training institutions will be made familiar with the BaCuLit curriculum and its standards. This will enable the trainers to flexibly use CAL elements in their training of teachers in their region. The general objective of ISIT is to carry out a comparative study - based on action research case studies in different countries - of "innovation management" in CPD. In the ISIT project the opportunities and obstacles in implementing innovative approaches in teachers $\mathrm{PD}$ are related to the implementation of CAL, but we assume that similar strategies could be applied in implementing other innovations. Thus these conclusions will be helpful for all actors in CPD. As a result we will present a Comparative Study of the gained experiences, accompanied by suggestions for implementing innovation in teacher education processes in the participating countries.

The ISIT project addresses two of the crucial needs defined by the Education and Training Benchmarks for 2020 and by the High Level Group of Experts on Literacy (HLGEL 2012):

a) the problem of low literacy skills in many European countries

b) the unsatisfying status of teachers' continuous professional development (CPD) in the EU.

Thus ISIT pursues two goals:

a) a specific goal: training 30 teacher educators from 3 European countries in content area literacy (CAL)

b) a general, comparative goal: analysing good examples 
of how to implement innovations into different national structures of CPD.

The innovative aspect of the project is to effectively combine these two goals.

The project follows a multiplier approach: by training teacher educators (narrow target group) it will reach out to secondary school teachers (second target group) which will have a positive impact on the long-term target group of students with low literacy skills (broadest target group).

ISIT builds upon the results of the Comenius project $\mathrm{BaCuL}$ it providing a comprehensive curriculum in CAL for $\mathrm{CPD}$, including course materials and trainer handbooks. ISIT aims at implementing this concept into the CPD structure of Germany, Hungary and Romania, where a total of 30 teacher educators from 25 different training institutions will be made familiar with CAL instruction.

The project follows an action research approach, which means not to separate research from action. Therefore the trainers will analyse together with scientists the steps and obstacles in implementing CAL courses in their institutions. Thus, ISIT intends to explore the general opportunities and obstacles in implementing innovation into teachers CPD in these 3 countries.

A further objective is the dissemination of CAL into 5 other countries: Partners from Belgium, Cyprus, Finland, Greece, and Portugal will participate gaining comparative insights and providing input from the perspective of their countries.

The project will start in spring 2014 Info-day at 4 locations: Arad, Iasi, Budapest, Frankfurt with an Info-Day. The topics are the following: (1) Report on the state of international research on reading with regard to CAL, (2) Discussion of implementation methods on the ground, (3) Invitation to the qualification of trainers.

\subsection{The EuLit Project}

The overall objective of our proposal is to develop a formal European Literacy Network, which will function as an umbrella organization for all associations, foundations, NGOs, research centres and other institutions dealing with the promotion of literacy in order to raise societal awareness of the importance of the issue of literacy and the opportunities that exist for improvement. It will raise awareness, gather and analyse information on literacy policies at a local, regional, national and trans-national level, and facilitate exchanges of expertise and experience with the sharing of good practice, effective policy approaches and promising campaigns and initiatives to promote literacy. The network will play a key role in supporting member states in achieving the Education and Training framework (ET2020) benchmark that the share of low-achieving 15 -years olds in reading should be less than $15 \%$ by 2020 .

We will analyse and consult on literacy policies at a local, regional, national and trans-national level, to raise awareness of literacy issues and to coordinate in-country campaigns. We will work in close cooperation with the
European Commission and national Education Ministries and other authorities in order to influence national literacy policies and to recommend future areas for research and intervention programmes.

We aim to establish a network that will enable key messages to be shared with all relevant stakeholders and organisations Europe-wide, inspire and align the long term campaigning strategies of our member organisations and promote literacy and reading through various activities' The project is located within the horizon of "learning skills" but focuses on "reading skills": It intends to extend secondary school teachers' expertise to improve their students' fluency, reading habits and comprehension strategies for diverse texts in all school subjects and to help them building a stable self-concept as readers and learners. Most urgent in this respect is to foster the so called "content area reading literacy" or "reading across the curriculum". The term "content area literacy" refers to teachers' competence to deal with reading/writing/learning instruction not only on the elementary level in the language arts classes, but in all subjects and all school levels. The project uses a "multiplier- and coaching-approach" which means that first, teacher trainers are educated and then will be supported in educating a first teacher cohort and in sustaining those teachers' change of classroom practice.

The basic curriculum will define the minimal knowledge every secondary content area teacher in the EU should have about teaching reading skills in all school subjects. It will provide 6 modules of 6 hours professional development course units each, including teaching material, collaborative tasks for improving one's own classroom practice and online support. Although the basic curriculum will only be implemented in 6 European countries, it will define the first overall European minimal standard for in-service teacher training in content area literacy. After being tested, the concept of the basic curriculum will therefore be downloadable on the project's website in English and the partners' languages.

\section{Conclusions}

The literacy research at Kecskemét College Teacher Training Faculty has aimed at finding scientific evidence for the problems of struggling adolescent readers, enhancing teachers' expertise in content area reading literacy and making the results of the projects known by wider public. Our goal is to support teachers in changing their vision of what it means to be an effective teacher of content. When students know how they can use reading and writing for learning content they become more successful learners which leads to feelings of success for both, teachers and students.

\section{REFERENCES}

[1] Garbe, Christine / Holle, Karl / Weinhold, Swantje (Eds.): 
ADORE - Teaching Struggling Adolescent Readers in European Countries. Key Elements of Good Practice. Lang: Frankfurt/M, et al. 2010.

[2] Steklács, J.- Szabó, I.- Szinger, V.: Olvasási nehézségekkel küzdő tizenévesek tanítása az Európai Unióban. (ADORE jelentés). www.nyelvpedagogia.hu 2010. 4 szám.

[3] Steklács, János - Szabó, Ildikó: Karakter munkafüzetek (szövegértési képességek fejlesztése olvasásstratégiai módszerrel). In: Erdei Ferenc VI. Tudományos Konferencia. II. kötet pp. 103-108. Kecskeméti Föiskola Kertészeti Főiskolai Kar, 2011. ISBN: 978-615-5192-00-5 II. kötet.
[4] Szabó Ildikó, Szinger Veronika, Steklács János (2011): Basic Curriculum for Teachers' Professional Development in Content Area Literacy in Secondary School. In: Hegedüs Orsolya, Psenaková Ildikó ed.: Science for education Education for Science I. Constantine University, Nitra, Slovakia, pp: 217-222.

[5] Steklács, János - Szabó, Ildikó - Szinger, Veronika: Nemzetközi BaCuLit-projekt az olvasáskészség össztantárgyi fejlesztéséért. In: Könyv és Nevelés XIII. évf. 2011/3. szám pp. $41-48$ 